\title{
Benign Leydig Cell Tumor
}

National Cancer Institute

\section{Source}

National Cancer Institute. Benign Leydig Cell Tumor. NCI Thesaurus. Code C4212.

A Leydig cell tumor which does not recur or metastasize. Morphologically, there is no evidence of cellular atypia, increased mitotic activity, necrosis, or vascular invasion. 